\title{
Evaluation of Level and Growth Factors of Mining Companies
}

\author{
Viktoriia Frolova $^{1}$, Olga Borisova $^{1}$, and Nadezhda Filimonova ${ }^{2}$ \\ ${ }^{1}$ Financial University under the Government of the Russian Federation, 125993 Leningradsky \\ Prospekt 49, Moscow, Russia, \\ ${ }^{2}$ Russian New University, 105005 Radio st., 22, Moscow, Russia
}

\begin{abstract}
The article reflects some aspects of the authors' research on issues related to the growth of mining companies. The authors analyzed the main approaches to assessing growth, revealed correlation dependencies between them, as well as factors of the industry and macroeconomic level. The study allows concluding that not all proposed models show the same dynamic trends, as a result, the authors proposed a reasonable choice of one of the models. The authors found that the important factors the development of which is necessary for the growth of companies and the mining industry as a whole are the restructuring of the business model, the transition to more active use of digital technologies and overcoming the effects of the pandemic. In addition, it is important for companies to maintain demand for their products, the achievement of which feasible through access to ecommerce sites and real-time trading.
\end{abstract}

\section{Introduction}

Recent decades have shown trends of a fundamental change in the economy. Periodic emerging crises, integration processes, globalization, labor migration, significant technological breakdowns and the transition to a digital economy are changing the traditional structure of established business relationships and affect the growth rate of key macroeconomic indicators. In such conditions of the Russian mining industry, it becomes difficult to survive and compete with foreign companies. However, many people understand that the future lies in technological development and the application of new green technologies. At the same time, alternative energy sources will lead to a decrease in demand for the results of labor in the mining industry. In accordance with SAP's forecast for the development of mining industry, by 2025 , in order to maintain a stable level of development, companies should switch to a business format that allows them to carry out activities in real time with a customer focus [1].

Business models of the future will be built on the basis of the interests and needs of customers. Modern technologies will significantly reduce the costs of companies, which will lead to a decrease in the need for assets involved in the production process and an increase in the financial result of mining companies. In particular, SAP notes that using 3D printing allows achieving reduction in costs of $50 \%-80 \%$ for surface mines, and blockchain technologies will ensure an increase in audit efficiency by almost 2 times [1]. Because of 
such measures, it will be possible to ensure the steady growth of individual companies, and, consequently, of the regions of which they are city-forming business units.

In connection with the indicated processes, the issues of assessing the sustainable growth of mining companies and its impact and, at the same time, depending on internal factors, the level of development of regions and macroeconomic indicators, are of particular relevance, which predetermined the goals of the authors' research.

\section{Materials and Methods}

A study conducted by the authors revealed the presence of several established approaches to the issue of economic growth. The researches, dealing with these issues, include the works of foreign and Russian authors, such as: Myovella G., Karacuka, M., Haucap, J., Kartaev F.S., Vorontsovsky A.V., Dmitriev A.L. and others [2]. Based on the provisions of these scientific works, the authors found that each model is based on certain postulates and contains various indicators aimed at reflecting various dependencies. In particular, Khotinskaya G.I. notes that the model of macroeconomic growth depends on certain measures of influence on the economic agents represented by companies [2]. There is criticism in the works of Russian authors related to the use of these indicators to assess corporate growth. The indicators used in the framework of the VBM concept, as noted by G.I. Khotinskaya, do not allow to obtain complete information about the state of Russian business, and V. Yakimov draws attention to the fact that the models have shortcomings that must be taken into account when predicting the growth of companies [3]. In particular, models have the assumption of a stable capital structure, asset growth proportional to sales [4].

The studies conducted by the authors revealed a set of methods that are appropriate to use to assess corporate growth. For this purpose, sustainable growth rates have been developed and are actively used, the SGR model, the Higins model, the achievable growth model of J. Van Horne, the acceptable growth rate of R. Wizwanathan, the BCG model, the Kisor, Lerner and Carleton model (for calculation, the indicators of internal reporting are used), model of Ulrich and Arlow, Rappaport and others [5]. Some of them are based on internal management information, for example, the interest rate on the company's borrowed capital (model of sustainable growth of Zacon, Lerner and Carleton), size adjustments and interest rates, and other factors (Gulati model and Zantoyta) [5]. For the study, the authors selected models containing indicators available for calculation by external users of information. The model calculations are based on profit indicators in many of its manifestations, the company's own and borrowed capital, assets, sales, and relative characteristics of the financial results of companies: asset turnover, financial leverage, variations in profitability ratios.

To study the growth of mining companies, a selection was made based on summarized data from the 40 largest global mining companies in 2009-2018. [4] The variation of corporate growth indicators for the world's largest mining companies for 2009-2018 is presented in Tab. 1.

Table 1. Assessment of corporate growth of the largest mining companies.

\begin{tabular}{|l|l|l|l|l|l|l|l|l|l|l|}
\hline Model name & $\mathbf{2 0 0 9}$ & $\mathbf{2 0 1 0}$ & $\mathbf{2 0 1 1}$ & $\mathbf{2 0 1 2}$ & $\mathbf{2 0 1 3}$ & $\mathbf{2 0 1 4}$ & $\mathbf{2 0 1 5}$ & $\mathbf{2 0 1 6}$ & $\mathbf{2 0 1 7}$ & $\mathbf{2 0 1 8}$ \\
\hline Kisor model & 0.08 & 0.16 & 0.15 & 0.04 & -0.03 & 0.01 & -0.12 & 0.01 & 0.04 & 0.04 \\
\hline $\begin{array}{l}\text { Ulrich and } \\
\text { Arlow model }\end{array}$ & 0.17 & 0.29 & 0.29 & 0.12 & -0.28 & 0.03 & 0.36 & 0.03 & 0.11 & 0.1 \\
\hline $\begin{array}{l}\text { Rappaport } \\
\text { model }\end{array}$ & 0.03 & 0.04 & 0.05 & 0.06 & 0.07 & 0.07 & 0.06 & 0.03 & 0.07 & 0.09 \\
\hline $\begin{array}{l}\text { J. Van Horne } \\
\text { model }\end{array}$ & - & 1.2 & 1.76 & 0.38 & 0.25 & 0.2 & -0.18 & 0.14 & 0.6 & 0.46 \\
\hline $\begin{array}{l}\text { Steady growth } \\
\text { rate (SGR) }\end{array}$ & 0.08 & 0.16 & 0.15 & 0.04 & -0.03 & 0.01 & -0.12 & 0.01 & 0.04 & 0.04 \\
\hline
\end{tabular}




\begin{tabular}{|l|l|l|l|l|l|l|l|l|l|l|}
\hline SGR model & 0.69 & 0.8 & 0.75 & 0.44 & -1.05 & 0.11 & 2.04 & 0.16 & 0.41 & 0.35 \\
\hline Higins model & 0.03 & 0.04 & 0.05 & 0.06 & 0.07 & 0.07 & 0.06 & 0.03 & 0.07 & 0.09 \\
\hline $\begin{array}{l}\text { Acceptable } \\
\text { growth rate of } \\
\text { R. } \\
\text { Wizwanathan }\end{array}$ & 0.07 & 0.13 & 0.13 & 0.06 & 0.02 & 0.04 & -0.03 & 0.02 & 0.06 & 0.07 \\
\hline BCG model & 0.01 & 0.02 & 0.02 & 0.03 & 0.03 & 0.03 & 0.03 & 0.02 & 0.03 & 0.04 \\
\hline
\end{tabular}

The data obtained as a result of the calculation, presented in Tab. 1, allowed the authors to conclude that the growth indicators of companies have a high level of variability depending on the methodology used. In particular, the Higgins and Rappaport models show similar values with insignificant dynamic changes in growth, while the SGR, Ulrich, and Erlow models are characterized by the same dynamic trends, but the steady growth coefficient of SGR with a higher amplitude in 2015 and 2017 reflects growth, and in 2013 - decrease. Obviously, dynamic changes in indicators do not show a general trend at the same time horizons, which, in turn, makes it difficult to make the right managerial decision, requiring a deep understanding of what factors affect the values of each indicator. Meanwhile, some techniques showed a significant level of direct correlation (Tab. 2).

Table 2. The correlation of corporate growth models of mining companies.

\begin{tabular}{|c|c|c|c|c|c|c|}
\hline Model Name & $\begin{array}{l}\text { Kisor } \\
\text { model }\end{array}$ & $\begin{array}{c}\text { Ulrich } \\
\text { and } \\
\text { Arlow } \\
\text { model }\end{array}$ & $\begin{array}{l}\text { Rappaport } \\
\text { model }\end{array}$ & $\begin{array}{l}\text { J. Van } \\
\text { Horne } \\
\text { model }\end{array}$ & $\begin{array}{l}\text { Steady } \\
\text { growth } \\
\text { rate } \\
\text { (SGR) }\end{array}$ & $\begin{array}{l}\text { Higins } \\
\text { model }\end{array}$ \\
\hline J. Van Horne model & 0.818 & & & & & \\
\hline $\begin{array}{l}\text { Steady growth rate } \\
\text { (SGR) }\end{array}$ & & & & 0.818 & & \\
\hline SGR model & & 0.933 & & & & \\
\hline $\begin{array}{l}\text { Acceptable growth } \\
\text { rate of R. } \\
\text { Wizwanathan }\end{array}$ & 0.982 & & & 0.881 & 0.982 & \\
\hline BCG model & & & 0.988 & & & 0.988 \\
\hline
\end{tabular}

As can be seen from Tab. 2, the highest correlation with other models is shown by the rate of acceptable growth of $\mathrm{R}$. Wizwanatan, combining the financial results of companies in the form of profit, sales and invested funds in assets with the definition of capital structure. Meanwhile, dynamic changes in indicators are predetermined by industry-wide, regional and macroeconomic indicators, while being constituent elements of the general system of economic relations at various levels. Accordingly, sustainable company growth should correlate with industry average and country indicators.

\section{Results and Discussion}

The analysis performed by the authors showed that the return on capital of the 40 largest mining companies is not high and varied over the study period from $-2.57 \%$ in 2015 to $11.67 \%$ in 2011 . On average, over the period it is $5 \%$. The average capital of companies over the study period for 40 companies showed a high level of dynamic volatility. The results of the correlation analysis suggest that such dynamics was caused by a significant effect of the size of sales $(\mathrm{R}=0.85)$ and profit $(\mathrm{R}=0.54)$. The capital structure of mining companies is predetermined by the high level of capital intensity of the industry, meanwhile, the ratio of borrowed and equity capital on the analyzed time horizon varies significantly, not confirming the condition that financial leverage in the companies of the industry remains unchanged, 
which is necessary for applying most growth models. At the same time, the authors revealed a tendency for feedback between profit growth and financial leverage $(R=-0.5)$, which is explained by an increase in capital charges as a result of attracting additional external sources of financing. Moreover, as noted above, macroeconomic factors affect the sustainable growth of mining companies.

To confirm this hypothesis, the authors evaluated the correlation, selected growth models with industry and macroeconomic indicators [5], the calculation results are shown in Tab. 3.

Table 3. Assessment of the correlation between macroeconomic indicators and growth indicators of the 40 largest world mining companies and their growth models.

\begin{tabular}{|l|c|c|c|c|c|}
\hline \multicolumn{1}{|c|}{ Indicator Name } & $\begin{array}{l}\text { Kisor } \\
\text { model }\end{array}$ & $\begin{array}{c}\text { J. Van } \\
\text { Horne } \\
\text { model }\end{array}$ & $\begin{array}{c}\text { Steady } \\
\text { growth rate } \\
\text { (SGR) }\end{array}$ & $\begin{array}{c}\text { SGR } \\
\text { model }\end{array}$ & $\begin{array}{c}\text { Acceptable } \\
\text { growth rate } \\
\text { of R. } \\
\text { Wizwanathan }\end{array}$ \\
\hline $\begin{array}{l}\text { 1. Indicators by industry } \\
\text { companies }\end{array}$ & & & & & \\
\hline $\begin{array}{l}\text { Profit growth rate for } \\
\text { companies }\end{array}$ & 0.542 & & 0.542 & & 0.563 \\
\hline Company sales growth rate & 0.854 & 0.862 & 0.854 & & 0.905 \\
\hline Company asset growth rate & 0.884 & 0.879 & 0.884 & & 0.878 \\
\hline 2. Macro indicators & & & & & \\
\hline Balance of profit and loss & & & & 0.544 & \\
\hline $\begin{array}{l}\text { Money Supply Dynamics } \\
\text { (M2) }\end{array}$ & 0.590 & 0.826 & 0.590 & & 0.657 \\
\hline Cash (M0) & & 0.580 & & & 0.532 \\
\hline $\begin{array}{l}\text { Non-cash money from the } \\
\text { non-banking system (MO) }\end{array}$ & 0.620 & 0.874 & 0.620 & & 0.680 \\
\hline $\begin{array}{l}\text { Volume Indices of Gross } \\
\text { Domestic Product }\end{array}$ & & 0.840 & & & \\
\hline $\begin{array}{l}\text { Russia's place in the Doing } \\
\text { Business ranking }\end{array}$ & 0.577 & & 0.577 & & 0.577 \\
\hline
\end{tabular}

The calculation results (Tab. 3) show the greatest degree of dependence of industry and macroeconomic indicators on the values of J. Van Horne's achievable growth; at the same time, the growth rates of assets and the sales growth rates of companies correlate with almost all growth models except SGR. In general, we can conclude that the growth models calculated by the authors have a direct relationship with the growth rates of sales, assets and profits for companies in the mining industry, which is quite natural, since the absolute values of these indicators are used in models for calculating growth rates. At the same time, a relationship was found between the growth of industry companies in the world and non-cash funds of the non-banking system of Russia, as well as the dynamics of the money supply. Based on this, the authors argue that the growth of mining companies will undoubtedly lead to an increase in the money supply in circulation mainly in the form of cashless funds. This fact will affect the increase in GDP and will strengthen Russia's position in the Doing Business ranking, which characterizes the ease of doing business in the country. An additional argument in favor of the studies is the studies of the aforementioned rating, which indirectly prove that the simplification of business rules is directly related to the growth of the economy due to the increase of its attractiveness for investors [6]. In turn, the steady growth of companies is largely affected by the economic situation in the country as a whole and in the region in particular.

In addition to the factors indicated above, industry-specific factors specific to the mining industry should be highlighted, which include: the level of competing imports, unfair competition, general demand for products, demand for products on the foreign market (export 
portfolio of orders), average level of capacity utilization, insufficient demand in the domestic market. Factors that determine the growth characteristic of a particular mining company are: stocks of finished products, number of people employed in production, dynamics of output of the main product in physical and value terms, insufficient financial resources, level of depreciation / lack of equipment, insufficient raw materials, and insufficient demand for company's products.

The absence or imperfection of the regulatory framework, anti-competitive actions of government bodies and local authorities, the insufficiency of highly qualified workers, the index of entrepreneurial confidence, a high level of taxation, the uncertainty of the economic situation, and a high percentage of commercial loans - all of thede also affects the company's growth. Fig. 1 (according to Rosstat [7]) reflects the dynamics of the results of a survey of mining companies on the level of external negative factors on the development of companies.

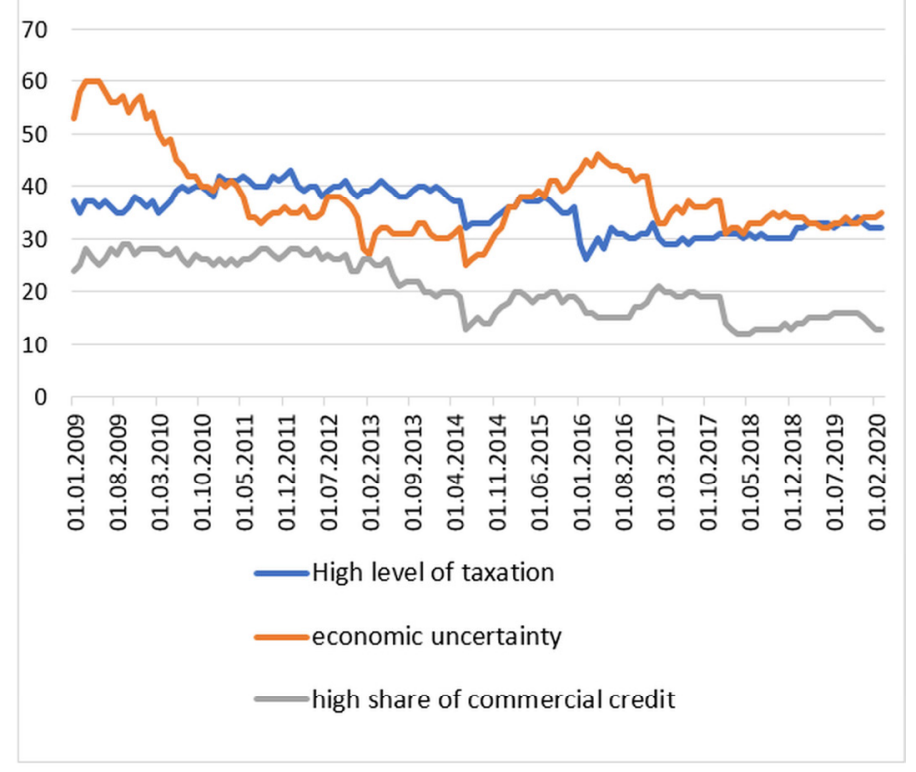

Fig. 1. The dynamics of the negative factors of the mining industry.

As can be seen from Figure 1, the maximum level of uncertainty of the economic situation was observed in 2009, then the situation stabilized, having a slight increase in 2016, at the moment there is a slight increase in the uncertainty of the economic situation, since the consequences of the pandemic are only gaining momentum. It is noteworthy that a high share of commercial credit is least worrisome in the mining industry, and a high level of taxation over a decade has not had a high level of volatility. The search for new solutions to overcome the totality of problems generated by the influence of internal and external factors of mining companies will ensure sustainable growth, even in a pandemic, as mining, manufacturing, providing electric energy, gas, steam and air conditioning are among life support.

In modern conditions, the key to sustainable growth of companies is the level of implementation and development of digital technologies [8-11], which at the initial stage requires significant investments, the return on which will manifest with a certain time lag, and this, in turn, in the transition period can lead to a decrease in growth rates [12-16]. Modern business models imply not only a customer orientation, but also a socially and environmentally oriented approach, which together will lead to an increase in the sustainability of companies and regions by providing jobs, replenishing the budget with tax fees, infrastructure improvement. 


\section{Conclusion}

The results of the study are based on a long-term trend of financial indicators, but as noted above, protracted pandemic control processes can significantly affect all spheres of economic activity. Maintaining sustainable growth of mining companies in modern conditions will directly depend on the degree of implementation of digital technologies, in particular, it is expected that by $2025,90 \%$ of new corporate applications will be built with artificial intelligence (AI). Obviously, this will affect the processes of optimizing offers, ensuring stable demand by organizing sales through e-commerce platforms, improving the quality of customer service through the formation of a customer feedback system. Meanwhile, the study allowed the authors to formulate several fundamental conclusions that can be used as a guide to forming the basis for making the right managerial decision.

1. The study showed a connection between the growth indicators of mining companies, their internal factors, as well as macroeconomic indicators. The analysis of various models for assessing growth allowed the authors to conclude that the rate of acceptable growth of R. Wizwanatan has the highest level of correlation with other indicators, while maintaining lowvariable values over a long time, and therefore can be used for initial express assessment of the growth level of companies. At the same time, specific growth factors for mining companies must be taken into account.

2. An indisputable factor in ensuring the high competitive position of mining companies is the integration of digital technologies in all processes of companies. At modern large companies, the beginning of the transformation of the labor force is observed, focusing on strengthening automation processes, mobility, augmented reality and cognitive abilities to increase productivity and work safety.

3. Making the right managerial decision is impossible without a preliminary assessment of previously accumulated information and expected forecast values. Ensuring sustainable growth of the company depends on financial results, the structure of assets and liabilities of companies, regulatory criteria, dividend policy, the influence of external factors of the industry, regional, federal and world level, in turn, the companies themselves are forming elements in the level of national welfare. Studies of factor dependencies are especially significant for mining companies, as their activities have a high level of integration with almost all types of activities, including access to export-import operations.

\section{References}

1. SAP, The intelligent enterprise in the experience economy for the mining industry. URL: https://www.sap.com/documents/2016/03/2eaf72d0-627c-0010-82c7eda71af511 fa.html

2. G. I. Khotinskaya, Manager, 4:56, 12-17 (2015)

3. V. A. Yakimova, Corporate Finance, 1:25, 81-95 (2013)

4. PWC, Mining. Resources for the Future (PWC, London, 2019)

5. M. Onder, I. N. Nyadera, International Journal of Public Administration, 43:4, 283-293 (2020)

6. Doing Business, Measuring Business Regulations. URL: https://www.doingbusiness.org/en/data

7. Rosstat, Federal State Statistics Service. URL: https://www.gks.ru/

8. O. Kalenov, E. Shavina, E3S Web Conf., 41, 04054 (2018)

9. O. Kalenov, S. Kukushkin, R. Kamanina, E3S Web Conf., 105, 04028 (2019)

10. O. Miliushenko, A. Kovalev, M. Zhidkova, E3S Web Conf., 105, 04046 (2019) 
11. M. Anastasov, N. Kazitskaya, I. Politkovskaya, E3S Web Conf., 105, 04043 (2019)

12. V. Frolova, O. Dolina, T. Shpilkina, E3S Web Conf., 105, 01054 (2019)

14. O. Ivanenko, E3S Web Conf., 105, 04025 (2019)

15. E. Dotsenko, N. Ezdina, A. Prilepskaya, K. Pivnyk, E3S Web Conf., 21, 04014 (2017)

16. T. Skryl, E. Shavina, E. Dotsenko, E3S Web Conf., 105, 04049 (2019) 